\title{
PENINGKATAN KESEJAHTERAAN MASYARAKAT MELALUI PEMANFAATAN LIMBAH BUAH JAMBU METE
}

\author{
Fatimah Riswati, Mei Indrawati, Dwi Lesno Panglipursari \\ UNIVERSITAS WIJAYA PUTRA SURABAYA
}

fatimahriswati@uwp.ac.id, meiindrawati@uwp.ac.id,dwilesno@uwp.ac.id

\begin{abstract}
Abstrak
Program ini dilaksanakan di Kecamatan Dasuk Kabupaten Sumenep dengan sasaran Desa Jilbudan dan Desa Beringin sebagai penghasil utama Jambu Mete. Program ini bertujuan untuk meningkatkan kesejahteraan masyarakat yang lebih baik melalui pemanfaatan sumberdaya lokal yang memiliki nilai ekonomi, peningkatan ketrampilan dan profesionalisme masyarakat, peningkatan kemampuan petani jambu mete untuk melakukan difersifikasi produk dan terbentuknya kelembagaan usaha ekonomi petani jambu mete yang terstruktur. Kegiatan ini menggunakan pendekatan pelatihan yang meliputi pelatihan ketrampilan dan kewirausahaan bagi para ibu dan karang Taruna, pelatihan ketampilan budidaya dan difersifikasi produk jambu mete secara profesional dan pelatihan pemasaran melalui internet; dan pendekatan pendampingan yang meliputi pendampingan alih teknologi difersifikasi produk jambu mete, pendampingan penguatan jaringan pemasaran dan pendampingan penguatan kelembagaan. Hasil yang didapatkan dari program ini adalah meningkatnya keterampilan dan jiwa wirausaha ibuibu dan karang taruna terhadap pengolahan limbah jambu mete menjadi produk olahan selai, manisan mete, pakan ternak, pembuatan label produk dan teknologi pengemasan produk mete serta terbentuknya Gapoktan dan jaringan kerja kelompok tani
\end{abstract}

Kata Kunci : Pelatihan, Pendampingan, alih teknologi

\section{PENDAHULUAN}

Kabupaten Sumenep memiliki wilayah daratan, lautan serta 126 pulau. Sumenep memiliki potensi sumber daya alam dan sosial ekonomi yang masih dapat dikembangkan dan dimanfaatkan untuk meningkatkan kesejahteraan masyarakat di sektor perikanan, perkebunan, pariwisata dan gas bumi.

Pemanfaatan potensi sumber daya alam di Kabupaten Sumenep belum optimal, sehingga nilai tambah ekonomisnya belum dirasakan sepenuhnya oleh masyarakat. Data Dinas Perkebunan Propinsi Jawa Timur tahun 2012 menyatakan Kabupaten Sumenep merupakan penghasil Jambu Mete terbesar di Jawa Timur dengan luas area perkebunan hingga 12.258 hektar.

Tabel 1. Luas Area Produksi Jambu Mete di Kabupten/Kota Jawa Timur

\begin{tabular}{lc}
\hline \multicolumn{1}{c}{ Wilayah Produksi } & Area (Ha) \\
\hline District of Sumenep & 12,258 \\
District of Sampang & 10,619 \\
District of Bangkalan & 9,466 \\
District of Ngawi & 3,083 \\
District of Pamekasan & 2,419 \\
District of Pacitan & 2,118 \\
26 other Districts & 12,940 \\
\hline Sumber : Dinas Perkebunan Propinsi Jawa Timur, 2012.
\end{tabular}

Teknologi Tepat Guna 


\section{Permasalahan Wilayah}

Selama ini hasil perkebunan buah Jambu Mete belum memberikan nilai ekonomi yang maksimal bagi masyarakat. Petani menjual produknya dalam bentuk biji/glondong mete karena berbagai keterbatasan petani, antara lain petani perlu cepat mendapat uang, skala produksi yang kecil /tidak efisien dan kekurangan sarana pengolahan. Hal inilah yang menyebabkan tingkat kesehjateraan petani perkebunan Jambu Mete secara umum masih relatif rendah. Padahal, seandainya buah jambu mete bisa diolah lebih lanjut sebagai bahan dasar untuk berbagai jenis komoditas olahan bahan makanan, maka ini akan bisa berdampak pada kenaikan kesehjateraan petani Jambu mete.

Salah satu penyebab utamanya adalah rendahnya kualitas sumberdaya masyarakat. Dari jumlah penduduk sebanyak 29.469 jiwa, lebih dari $90 \%$ berstatus belum tamat SD, dan $5.50 \%$ tamat SD.

Tabel 2. Jumlah Penduduk Berdasarkan Jenjang Pendidikan

\begin{tabular}{crc}
\hline Jenjang Pendidikan & \multicolumn{1}{c}{ Total } & In percentage \\
\hline Belum Tamat SD & 26.487 & $91,10 \%$ \\
SD & 1.621 & $5,50 \%$ \\
SMP & 538 & $1,83 \%$ \\
SLTA & 351 & $1,19 \%$ \\
Diploma/Sarjana & 112 & $0,38 \%$ \\
Jumlah & 29.469 & $100 \%$ \\
\hline
\end{tabular}

Sumber : BPS, 2013, Diolah.

Tingginya jumlah penduduk yang memiliki tingkat pendidikan sangat rendah menimbulkan permasalahan kualitas sumberdaya manusia yang rendah yang berimbas pada keterbatasan dana, sarana dan prasarana untuk pengembangan sehingga kemampuan masyarakat untuk meningkatkan kualitas hasil perkebunan menjadi rendah serta tidak mampu mengaplikasikan kemajuan teknologi, inovasi dan teknik pemasaran Jambu Mete dan limbahnya untuk menjadi bahan yang lebih berguna dan memiliki nilai ekonomis tinggi.

\section{Teori Kesejahteraan}

Kesejahteraan secara umum merupakan keadaan dimana segenap warga negara tanpa kecuali dan dimanapun berada, selalu dalam keadaan serba kecukupan segala kebutuhannya baik materiil maupun spiritual, keamanan dan ketertiban terjamin, hidup tenteram dan damai, jauh dari kejahatan dan tidak saling mencurigai, serta seluruh aparatur negara bersatu menjunjung kewibawaan bangsa dan negara.

Hahnel (2005) mengkalisifikasi teori kesejahteraan menjadi classical utilitarian, neoclassical welfare dan new contractarian approach.

Classical utilitarian menekankan bahwa tingkat kepuasaan seseorang dapat diukur dan bertambah serta dapat dibandingkan secara kuantitatif. Neoclassical welfare mempopulerkan prinsip Pareto Optimality, yakni masyarakat akan menjadi lebih baik jika kualitas setiap individunya meningkat. Sedangkan New contractarian approach, menyatakan bahwa setiap individu memiliki konsep adanya kebebasan maksimum dalam hidupnya.

Ketiga pandangan tersebut menekankan bahwa tingkat kesejahteraan seseorang sangat tergantung pada tingkat kepuasan dan kesenangan yang dapat diraih dalam kehidupannya. Tingkat kesejahteraan yang tinggi dapat tercapai bila suatu perilaku mampu memaksimalkan tingkat kepuasaan sesuai dengan sumber daya yang dimiliki.

Secara garis besar kesejahteraan dapat diukur melalui indikator ekonomi dan indikator nonekonomi (sosial) (Todaro, 2017:234).

\section{Indikator Ekonomi}

Pendapatan per kapita sering digunakan sebagai indikator ekonomi atau indikator moneter. Pendapatan per kapita memberi gambaran tentang laju pertumbuhan kesejahteraan masyarakat pada berbagai negara, juga mampu menggambarkan corak perbedaan tingkat kesejahteraan masyarakat berbagai negara.

Pendapatan per kapita sebagai indikator kesejahteraan mempunyai kelebihan mampu memfokuskan pembangunan pada kenaikan tingkat hidup dan menghilangkan faktor kemiskinan. Pendapatan per kapita adalah indikator kesejahteraan terbaik yang ada pada saat ini.

\section{Indikator Sosial}

Indikator tingkat kesejahteraan dari setiap negara ditentukan berdasarkan kepada tingkat konsumsi atau jumlah persediaan beberapa jenis barang tertentu dengan data yang mudah diperoleh, seperti harapan hidup, konsumsi protein hewani, konsumsi energi, konsumsi listrik dan konsumsi baja 
Human Development Index (HDI) atau Indeks Pembangunan Manusia (IPM) digunakan untuk menentukan peringkat semua negara dari skala nol untuk tingkat kesejahteraan paling rendah hingga skala 1 untuk nilai tingkat kesejahteraan manusia tertinggi (Todaro, 2017:68).

Tingkat kesejahteraan disusun berdasar tiga komponen, yaitu 1) angka harapan hidup yang diperoleh dari perhitungan rata-rata jumlah anak lahir yang hidup dan jumlah rata-rata anak masih hidup menurut kelompok umur ibu 15 - 49 tahun; 2) Tingkat pendidikan yang diukur menurut indikator angka melek huruf dan rata-rata lama sekolah; dan 3) standar hidup layak, dengan menggunakan rata-rata pengeluaran perkapita riil.

\section{Target Luaran}

Target yang ingin dicapai program ini adalah terjadinya peningkatan 1) kesehjateraan masyarakat melalui pemanfaatan sumber daya lokal, 2) keterampilan masyarakat lokal, 3) kemampuan untuk melakukan difersifikasi produk, dan 4) terbentuknya usaha ekonomi dan kelembagaan masyarakat yang terstruktur.

Upaya Pemerintah Kabupaten Sumenep untuk meningkatkan kesehjateraan masyarakat melalui pengembangan ekonomi lokal telah tertulis pada RPJMD Kabupaten Sumenep Tahun 20112015. Untuk mencapai misi ini, telah dilakukan penyuluhan-penyuluhan, diskusi dengan Forum Informasi Masyarakat (FIM) Sumenep, dan pelatihan pengelolaan lahan perkebunan yang disesuaikan dengan kontur tanah. Kendala terbesar adalah tingkat pendidikan yang rendah dan pola pikir sebagian besar petani yang masih pragmatis, yaitu bagaimana bisa segera memperoleh uang dalam jangka pendek dan cepat untuk bisa memenuhi kebutuhan hidup mereka.

\section{METODE}

Metode pemandirian dan pensejahteraan masyarakat dilakukan penanganan dari tiga aspek kemasyarakatan yaitu 1)aspek Pendidikan melalui penyuluhan dan peningkatan pengetahuan tentang kewirausahaan dan budidaya Jambu Mete untuk meningkatkan nilai ekonomis; 2) aspek agribisnis dan teknologi pangan melalui pengenalan teknologi tepat guna bagi pengelolaan Jambu Mete dan limbahnya; dan 3) aspek manajemen pemasaran dari sisi pengemasan dan distribusi produk.

Wilayah yang ada di Kabupaten Sumenep yang punya potensi untuk berkembang dan mandiri adalah Kecamatan Dasuk yang memiliki luas wilayah $64,50 \mathrm{~km}^{2}$ dan merupakan penghasil buah Jambu Mete terbesar di Kabupaten Sumenep. Hasil biji Jambu Mete dari wilayah ini banyak yang diekspor keluar pulau dan luar negeri. Sayangnya, tingkat kesehjateraan petani perkebunan dan masyarakat di wilayah ini secara umum masih relatif rendah. Lebih khususnya program ini dilaksanakan di Desa Jilbudan dan Desa Beringin.

\section{Metode Pelaksanaan}

Dua pendekatan dalam metode pelaksanaan in adalah kegiatan pelatihan dan pendampingan

\section{Proses Pelaksanaan}

Secara proses, pelaksanaan untuk masingmasing program solusi permasalahan adalah sebagai berikut : 1) program pendidikan dan pelatihan kewirausahaan akan diberikan kepada masyarakat baik yang sudah memiliki usaha maupun yang ingin membuka usaha- dalam bentuk penyuluhan, simulasi dan pendampingan dengan materi meliputi motivasi wirausaha dan manajemen pengembangan usaha, dilanjutkan dengan simulasi. Untuk memantau penerapannya, tim akan melakukan pendampingan sekaligus sebagai konsultan; 2) program peningkatan budidaya produksi dan kualitas jambu mete melalui pengembangan teknologi pengolahan pupuk (Suhartini dan Nurika, 2018), dan pengolahan jambu mete dari jambu mete gelondong menjadi kacang mete; 3) program peningkatan teknologi pengolahan untuk diversifikasi produk jambu mete menjadi aneka makanan sari buah, sirup, selai, keripik, dan abon, 4) program peningkatan teknologi untuk mengolah limbah jambu mete menjadi pakan ternak melalui teknologi serbuk kering, metode silase dan metode fermentasi; 5) program pengembangan bisnis meliputi pelabelan dan pengemasan produk dilakukan melalui pelatihan bagaimana melakukan pengemasan yang higienis dan pelabelan yang memberi nilai jual; 6) program peningkatan teknologi pemasaran produk melalui kegiatan penyuluhan pemasaran, promosi dan pelatihan menggunakan komputer untuk pemasaran melalui media jaringan online; 7) penguatan kapasitas

$$
\text { Teknologi Tepat Guna }
$$


kelembagaan dengan membentuk gapoktan (gabungan kelompok tani).

\section{Perguruan Tinggi Mitra}

Program ini menjalin kerjasama dengan Universitas Wiraraja Sumenep dengan alasan 1) posisi institusi berada di wilayah sasaran program akan memudahkan koordinasi, 2) Lebih mengenal karakter masyarakat Sumenep, 3) staf dosen yang terlibat sesuai dengan spesifikasi yang dibutuhkan, yaitu ahli dalam bidang teknologi tepat guna dan lagi ahli dalam bidang manajemen.

\section{Kontribusi Pemerintah Daerah Kabupaten Sumenep}

Dalam pelaksanaan program ini, pemerintah kabupaten Sumenep memberi kontribusi berupa 1) dana pendamping dari dana LLDIKTI untuk pendidikan dan pelatihan dan pembelian bahan serta peralatan yang diperlukan, 2) memfasilitasi komunikasi dengan masyarakat dan aparat terkait, baik pada tingkat desa maupun pada tingkat kecamatan, 3) mengkomunikasikan program ke SKPD terkait agar dapat merencanakan kegiatan yang bersinergi selama masa pelaksanaan program, 4) melibatkan sejumlah staf pemda yang terkait dengan bidang tugas nya dalam pelaksanaan program untuk dukungan dan pembelajaran.

\section{HASIL DAN PEMBAHASAN}

\section{Program Pendidikan dan Pelatihan Kewiraausahaan}

Kemampuan ibu-ibu PKK dan Karang Taruna dalam motivasi berwirausaha, membuat business plan dan manajemen pengembangan usaha meningkat. Pelatihan yang diberikan adalah ketrampilan pembuatan aneka hiasan dan asesoris pakaian dari olahan bahan limbah kulit kacang mete dan dihadiri 50 orang wakil desa.

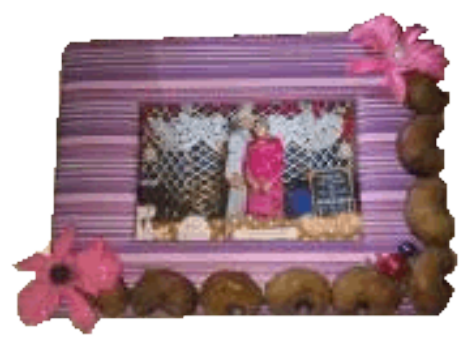

Gambar 1. Pigura dari bahan rajutan dan kulit kacang mete
2. Program peningkatan budidaya produksi dan kualitas jambu mete

Mengenalkan proses pembuatan pupuk organik dari kulit buah mete yang dicacah dan dihaluskan. Kami membuatkan alat pencacah dan penggiling kulit otomatis yang menghasilkan serbuk kering.

\section{Program peningkatan teknologi pengolahan}

Penyuluhan dan workshop peningkatan teknologi untuk diversifikasi pengolahan buah jambu mete menjadi aneka makanan sari buah, sirup, selai, keripik, dan abon. Melalui program ini kami membuatkan alat untuk memeras buah jambu mente menjadi sari (jus) dan ampas secara otomatis.

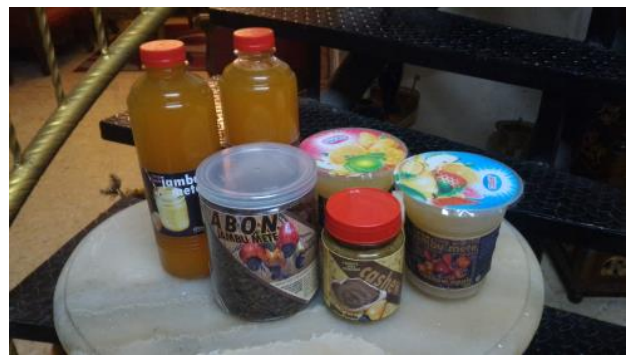

Gambar 2. Sirup, abon, sari buah jambu mete

\section{Program peningkatan teknologi untuk limbah jambu mete}

Mengenalkan pengetahuan dan proses pengolahan aneka limbah jambu mete seperti kulit kacang mete dan badan buah jambu mete menjadi pakan ternak melalui dengan 3 metode menurut Bikas (2016), yakni serbuk kering, metode silase dan metode fermentasi.

Komposisi penggunaan pakan ternak dari limbah jambu mete ini adalah 30\% dari total pakan ternak. Pakan ternak dari limbah buah mete ini menghasilkan peningkatan protein $12 \%$ hingga $20,84 \%$

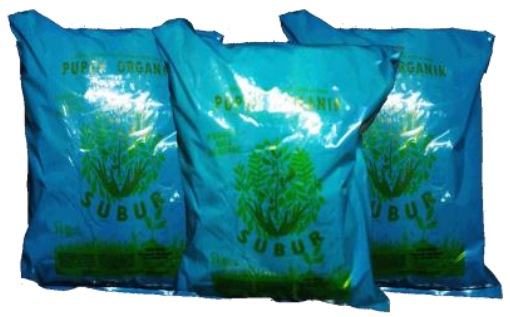

Gambar 3. Pupuk dari limbah buah jambu mete Teknologi Tepat Guna 


\section{Program Pengembangan Bisnis}

Penyuluhan dan pelatihan mengenai pengemasan produk media plastik atau kaleng yang benar dan higienis, baik produk kacang mete maupun diversifikasi produk jambu mete lainnya. Dilanjutkan secara sinergis dengan pelatihan membuat desain label produk yang menarik serta bagaimana mengurus hak merek atas produk yang dijual.

\section{Program peningkatan teknologi pemasaran}

Kegiatan penyuluhan mengenai teknikteknik pemasaran dan promosi serta pelatihan menggunakan komputer untuk pemasaran melalui media jaringan online.

\section{Penguatan kapasitas kelembagaan}

Membentuk gabungan kelompok tani, yang kemudian dilanjutkan dengan membentuk jaringan kelompok tani. Diharapkan dari jaringan kelompok tani ini, maka komunikasi dan kerjasama antar kelompok tani ini bisa dilakukan untuk memperkuat pemasaran produk mereka keluar, bahkan bisa sampai ekspor.

\section{KESIMPULAN}

Program penularan pengetahuan beserta pendaya-gunaannya kepada komunitas petani jambu mete di Desa Jilbudan dan Desa Beringin, Kecamatan Dasuk, Sumenep, memberikan dampak positif, yakni kini para petani jambu mete mampu memanfaatkan limbah, baik badan buah maupun kulit menjadi produk-produk yang memiliki nilai artistik dan nilai ekonomis.

Pendapatan dari penjualan pemanfaatan limbah jambu mete ini memberikan penghasilan tambahan bagi komunitas tersebut yang diharapkan dapat meningkatkan taraf hidup masyarakat menuji komunitas yang mandiri.

\section{REFERENSI}

Huang, X., \& Xie, Y. M. (2010). Evolutionary Topology Optimization of Contimuum Structures: Methods and Applications. Chichester: John Wiley and Sons, Ltd. Publication.

Nayani ZS, Hendre PC. (2015). Comparision and Correlation of Pap Smear with Colposcopy and Histopathiology in Evaluation of Cervix. Journal of Evolution of Medical and Dental Sciences, 4(53): 9236 - 9247.

Asosiasi Pengguna Jasa Internet Indonesia (2016). Penetrasi dan Perilaku Pengguna Internet Indonesia, Survey 2016.

Badan Pusat Statistik, 2013, Kecamatan Dasuk Dalam Angka 2013, Biro Pusat Statistik Kabupaten Sumenep Jawa Timur, Sumenep.

DP2M Dirjen Dikti, 2013, Panduan Pelaksanaan Penelitian dan Pengabdian Kepada Masyarakat Edisi IX, Kementrian Pendidikan dan Kebuadayaan, Jakarta

Hahnel, R. 2005. Economic Justice and Democracy: From Competition to Cooperation. Brighton: Psychology Press.

Pati, BR. Mandal, SM. 2016. Recent Trends in Bioferilizers. New Delhi: IK International Publishing House

Pemerintah Kabupaten Sumenep, 2011, Rencana Pembangunan Jangka Menengah Daerah Kabupaten Sumenep Tahun 2011-2015 - RPJMD, Sumenep

Saragih YP. Haryadi Y., 1994, METE, Budidaya Jambu Mete. Pengupasan Gelondong. Bogor: Penebar Swadaya.

Suhartini, S. Nurika, I. 2018. Teknologi Pengolahan Limbah Agroindustri. Malang: UB Press.

Todaro, MP. 2017.Economic Development, $12^{\text {th }}$ Edition. Ne Delhi, Pearson . 